\title{
Excellent Local Culture To Foster The Core Values Of The Local College Students
}

\author{
Wang Yanli, ${ }^{1, a}$ \\ ${ }^{1}$ Primary Educational Dept., Wuhan City Vocational College, Wuhan, Hubei, PRC Postal Code: \\ 430067 \\ awangyanli1967@126.com b472207066@qq.com
}

\author{
Keywords : Local culture Foster Local Universities Core Values
}

\begin{abstract}
To local geographical and cultural connotations of stretch point, demonstrates the enormous cultural significance and role of local excellent place to nurture the core values of college students, when presented with excellent local culture nurture the core values of the local college students.
\end{abstract}

\section{The local culture and connotations}

The word "culture" first appeared in ancient China in the Book of Change: "Judging from astronomy, varying with the police; judging from the humanities, to into the world." Liu Xiang in the Western Han Dynasty, 《ShuoYuan》 said:. "Sage rule the world but also, first and then force who Wende Wu Xing, is also satisfied, culture does not change, then add punish.” Culture as a social consciousness, was given a certain mental attributes, with the spirit of the common people probation educational function.

The so-called cultural resource is human to open up, develop and improve their environment for survival, in the transformation of the use of natural, maintaining social norms and shaping the material culture of human beings in the process of creating long-term practice, the institutional culture (social and cultural) and spiritual cultural resources. Local development process which condenses historic relics, artifacts, museums, monuments, mausoleums and other material belonging to cultural resources, and customs in the long-term development process of the formation of regional spirit within the scope of spiritual and cultural resources. Cultural resources is intangible, heritage, stability, shared, persistence, performance maximum resistance, incremental and other characteristics, the development of human society plays a role in directionality, supportive, cohesive driving force. [1]

China's vast territory, throughout the long history of cultural development in the formation of a unique cultural resources - the local culture. Local culture is the culture of the local population composed of different, are individuals or groups in the course of growing cultural environment could affect their perception, thinking and values of the formation of local culture is a culture within the local original form, for After the local cultures, habits and ways of thinking affect the nation's re-interpretation of culture, traditional culture is a culture in the form of integration and development. Around the local culture has a very different, there are different values, and culture and behavior. "Unique", "Rare" or "otherness and Mo" is the most important prerequisite "local culture” judgment.

"One country support person." Local culture and cultural heritage is one of the long history of regional development, is a country, a nation indispensable spiritual habitat. Local culture, is not only a very substantial economic resources, but also a cultural cornerstone for further development and the creation of social transformation is to achieve the great rejuvenation of the Chinese nation, "China Dream" powerful thrust.

\section{Local indigenous culture into higher education is the trend}

Modern educational theory is that there is a certain cultural resources is a necessary condition constitutes education. Certain areas of the local culture provides both for mankind a specific historical background and living space, it is often the "constraints of an invisible force that local resident thinking ideas, ways of thinking, values, morality, lifestyle, etiquette system , customs and religious beliefs, but inevitably the local technology and literary arts education has a profound influence "[2]. Each city has its own unique regional local culture, these cultures contained many 
fine cultural traditions, such as harmony, patriotism, honesty, etc., is an important source of national cohesion and creativity of a country is an important core value system to build community content.

Unfortunately, in the culture of "globalization" shock wave, China's local culture and traditional culture of the world, like many of the nation's cultural values, cultural traditions and national dignity faced unprecedented challenges, some of which can best reflect the national characteristics The local culture is disappearing, and some even die. China's local education collective aphasia and caught a state of shock, many students exhibit strange for local culture and flee for their home culture seriously alienated. Investigation I found that many students can not tell from his hometown out their home landscapes, customs and habits are unaware of their hometown; students have educated proud to employment outside the home, ashamed to return home to survive. There are so popular jingle portray contemporary college students: "farm better than I, doing business as good as sister-in-law, sister knows the weight is better", this sentence reflects the image of the current Higher Education students out of a serious lack of knowledge and ability to solve local problems. The current Chinese educational neglect to adhere to the local culture, which is one of the biggest mistakes of our current educational and cultural functions. Containment fundamentally improve this phenomenon, re-emphasize the importance and uniqueness of the local culture, strengthen students' sense of national consciousness and local, is necessary and very urgent.

November 2012, the party's 18 proposed “to cultivate and practice the socialist core values" of great ideas. March 2013, the President Xi Jinping speak in the second session of the first meeting, nine references to "China Dream", a concept, and pointed out: "China must take to achieve the dream road China must carry forward the Chinese spirit, we must unite China force. "Central to this series of initiatives, "China", "nation", "Chinese traditional culture" has a rich Chinese cultural concept of local color highlights out. So once again into the local culture education vision of society. March 26, 2014, the Ministry of Education issued "perfect Chinese traditional culture education Guidelines" clearly "under the new situation to further strengthen the excellent traditional Chinese culture and education.” Party and the government has fully recognized from a strategic and political education to the local culture is beneficial to the nation-state Chiaki plans. Trend, which is the implementation of local colleges and universities to ensure that local education politics and the best opportunity.

\section{To carry out local culture local university education is the question of meaning}

Universities are important cultural information exchange carrier and an excellent platform for cultural heritage, but also the national cultural revival of hope and future. The birth of an institution of higher learning, they tend to promote the rapid development of a particular region. State University has always been to build a cultural center and regional development. While each university has a specific geographical location, in a specific geographical and cultural environment, the development of these areas is bound to be affected by the unique local culture, while building distinctive local university is ultimately a specific geographical and cultural nourishment. Famous British scholar E - Ashby said: university "preserve, disseminate and rich human culture it like animals and plants evolved so as to forward any type of universities are the product of heredity and environment...” [3] any one university can be separated from the geographical talk about the economic and cultural development.

General Secretary Hu Jintao to celebrate the 100th anniversary of the founding of Tsinghua University's important speech in the General Assembly stressed that: "Higher education is an important source of outstanding cultural heritage and an important carrier of ideological and cultural innovation." University education as a social and cultural institutions, carrying the tradition, innovation and the important mission of advanced culture and spiritual civilization. Local university is undertaking the task of training highly qualified personnel for the local economy and culture. In the "globalization" in the background and the discourse system, local cultural heritage are the responsibility of higher education is more urgent than ever before. "In the face of pressure from the global proliferation of pseudo-culture to defend their cultural identity, the university should be the main source of this ...... not the great cultural achievements of the nation's heritage and values thrown into neglected corners." [4] as a local colleges and universities, the biggest feature is endemic, its main object-oriented personnel training personnel areas. Local college talent cultivation target directly determines the work of personnel training local colleges and universities must be rooted in the fertile soil of the local culture. As a local university, only based on local, 
relying on local, fully excavated, the use of foundation of historical and cultural resources of the region, to strengthen education for students of local culture, and actively cultivate outstanding culture to local college students socialist core values, people build a better spiritual homes, to create a good atmosphere geographical humanistic spirit, improve people's mental state, local culture "know much, well done, stay," the high-quality talent to the successful completion of higher education, "Rucker tree people" fundamental tasks.

\section{In order to foster local culture core values of college students}

Values are a group of its members to abide by a set of values and norms, is the position of the people on the value of a certain historical period issues held, the sum of the views and attitudes. Human values through the evolving role of culture is the core culture. "Exists in a variety of explicit and intrinsic patterns which, with the use of symbols to learning and communication, and constitute special achievements of human groups, including their specific design of these achievements manufactured goods by the ideas and values of traditional culture consisting of basic core, especially for the most important value "[5]

A local area contains a wide range of content and cultural resources, both material and cultural, but also spiritual culture, culture is a typical representative of these pending regional culture, with strong penetration beyond time and space and influence, is an important resource for local economic development strong force protection and development of cultural industries. In a lot of content in local culture, social values as the core of the national spirit, the humanities and scientific spirit is the most important spiritual and cultural resources. Safeguarding intangible cultural unity and social stability, coordination relationships, regulate people's behavior, adjust people's emotions, people's hopes pinned "God", the core values of the college is to cultivate a huge treasure and powerful weapon.

Contemporary society, "globalization" shock wave makes the commitment to maintain the original education and national culture heritage, nurturing offspring spiritual values undermined social function of lost faith and spiritual traditions of loss, of ethics, values become critical and rebellious one thought. These "lost value" phenomenon, brought to our education an unavoidable topic - what kind of content to nurture our successors values. Educator Jaspers once said: "Education is the great cause extremely serious, by cultivating a new generation of people constantly bring outstanding culture of human spirit, and to let them in the full spirit of life, work and communication." select the social core values advocated by the State led the school's educational function display, for young people to guide and regulate the value gradually cultivate and establish values in line with social development and personal development of students is our mission to educate people each, Education is also a long-term goal.

4.1, Cultivating students' cultural roots "local awareness, strengthen national spirit. Enhance national cohesion.

To achieve the great rejuvenation of the Chinese nation's dream of becoming China today. China needs a realization of a dream from the state to the individual's social "common point" - national cohesion. National cohesion is the nation's cultural identity as a carrier, is a nation with the ability to self-sustaining and unifying the fundamental, is the nation closer together spiritual power. Enhance national cohesion, requires us to establish a common belief in the value system - the socialist core value system, foster socialist core values, the spirit of the Chinese nation and the baptism of the soul unfold, making the Chinese identity, cognitive core.

Enhance the cohesion of the nation lies in the cultivation of local consciousness, to establish the value of identity. In the human growth process, Hongo local culture, customs and other dialects plays a profound role in the subtle influence. Since the date of birth of a person, he was placed in a realistic environment exists, he has a genetic ancestry and national culture and heritage in this is the national spirit of the chain begins to release its genetic potential into reality have been saved Based on the continuation and future cultural ethos of the starting point, and also the process of evolving individual culture, local culture is human "origin" and "root." Local cultural cohesion of the nation, the region's unique culture and a strong personality spirit form, implies a way of thinking of the nation and the world's cognitive style. Any regional cultures have to cultivate national temperament, shaping the national spirit, national culture heritage features, is a nation relies Xing foundation of a nation to gather spiritual core stability, it is a source of national cohesion and centripetal force. The individual members of ethnic groups also tend to build the overall sense of national identity and 
cultural identity through the vest. Weakening of national culture and national spirit destroy it often means that the decay and collapse of their homes. Therefore, the seventh session of the Sixth Plenary Session "CPC Central Committee on deepening reform of cultural system to promote development and prosperity of socialist culture and a number of views on major issues decided" that: "Culture is the nation's blood, is the spiritual home of the people, culture has increasingly become important source of national cohesion and creativity. " Endless cultural vitality, can enhance the nation's cultural cohesion, solidarity. Building a culture of power, that is, through the integration of cultural resources gathered to form lasting, strong cultural identity, so get promoted national cohesion and achieve the great rejuvenation of the Chinese dream.

From this perspective, the implementation of the local culture and education, which is to build students' search for the origin of "the cultural roots awareness, foster national feelings of students, education continues to fulfill the national spirit and culture to enhance national cohesion, the important mission of building the national spirit. By consciously indigenous cultural education for students to re-recognize their own native culture that nurtures in the process of learning and thinking, foster local awareness, establish national sentiment, to enhance its local cultural identity and national identity - to the motherland the high degree of recognition of the nation's highly recognized, highly appreciated the Chinese culture and a high degree of recognition of socialism with Chinese characteristics. This identity is the spirit of our nation for generations continuation blood conducive endless proliferation of great national development and rejuvenation, helps to "China Dream" at an early date.

4.2 Foster homes patriotic feelings and consciousness of college students.

Construction of cultural power and achieve the great rejuvenation of the Chinese nation depends fundamentally enhance national cohesion, the final crystal national cohesion is the national consciousness, national spirit. National consciousness is the attitude of people in the historical process of the formation of the state, emotion, cognition, but also beliefs, customs, complex exists in the form of recognition of the value of people, and it goes beyond kinship, ethnicity, language, geography, religion or tradition, is shaping cultural identity, based on the value of the Chinese nation to build a collective identity. Chinese cultural tradition since ancient times "isomorphic home country," the social and political philosophy. Ch'u legal historians believe that it is generally the situation in China, is the home for the family, family is family, the former is an economic unit, are living together groups; latter is a combination of the former, is a blood units. Each home has since become one economic unit. China's political and religious club to ethics-oriented, so the family is very closely related to politics and, family, Han is regarded as even more important to support the National Society cherry. "Isomorphic home country" is the social basis for the existence of Confucian culture, ancient "Sacred Hearts, self, family, country and the world," the individual layers of progressive ideals, reflecting among family, clan, ethnic and national This homogeneity contact. Thus, for Chinese people, the love of home, love of country and thus is a natural thing.

Patriotism is a profound feeling, a deep attachment to the land and grow their own feelings and cherished nation, nations of the world the Chinese nation stand on a strong spiritual power. The first is patriotic to their home from the in-depth understanding, love their homeland began. Zhou Enlai such a great man once said: "A love of the motherland, who are not love their hometown." Hard to imagine that a home does not even love will love our community will love our country. China has always attached importance to education after the local culture and national consciousness of the people culture, Confucian "repair Qi Zhiping” is the highest expression of home country education. Especially in modern times, the influx of foreign culture is to promote awareness on the local, national consciousness unprecedented awakening. A group of pioneers of modern education, the influence by Germany and Japan, the home of the local emphasis on the recognition of the community of life and hope through local education and patriotic education, stimulate national homeland from this small community to this great community ownership of the country sense, so as to build a modern nation-state services. In 1905 the Qing government promulgated the "Local Records head cases," the official implementation of the local culture laid the forging of national education basic pattern of the national spirit from the government level. After the Revolution, the government of the Republic, the base, the new China, in all of the educational decrees, regulations, curriculum standards, and always reflects the importance for local education, local education fully affirmed the local cultural heritage and national culture, to achieve local recognition cultivate native emotion, construct the national consciousness of great value. 
Local culture is a culture of most national characteristics, is a student able to appreciate their own culture around the most real. With excellent local cultural resources into education, not only is the process of a long-neglected folk cultural resources into mainstream education, a national historic continuation of the life blood of memory, but also a spirit of survival and the survival of the nation and the wisdom of the Living Culture presence awareness and recognition processes. People on the geographical and cultural awareness and recognition contributes to human form home - family Township - country as a whole, with a patriotic love for their homeland as one of the emotions and understanding. Through education, college students further in-depth knowledge and understanding of the home culture, long history and splendid culture and hometown pride, increased emotional loving home, home building, and thus elevated to patriotism.

4.3 To improve the quality of humanities students, college students shaping sound personality.

One of the biggest features of native education, that it is culturally specific place in their native lands, the students understand the home as educational content. "Every kind of regional culture is based on the unique geographical environment, under the combined effect of political, economic, cultural and other factors historically formed ...... living in the same geographical groups, the basic framework of cultural and psychological structure of each person, will be subject to the subtle influence of local culture, shaping the cultural psychology of the individual personality with a certain geographical and cultural characteristics, needs, motivation, will, emotions and other content. "[6] Lao She has repeatedly expressed himself with the ancient city of Beijing relationship: "It's in my blood, my personality and temperament, there are many places in this ancient city has given" "I have every miss in Peking"; He added: "I was born in Peking, where the personnel, landscape, taste and sell plum crying voice, I totally familiar with my eyes closed Peking would like a full color vivid picture in my mind floats upright and I'm bold depiction it. “

Thus, we can see that the cultural and psychological qualities of a person plays a decisive role in his social environment. In the educational process, the development of local cultural resources and student EQ combines not only enables students in the familiar "local atmosphere" and close the "affinity" in contact with the historical, historical stories, such as home direct, sensual material culture, more profound experience of local culture inherent values, cognitive attitudes, ways of thinking, spiritual and cultural traditions of folk. To help students through their side of the cultural phenomenon, understand their culture, experience and understanding of their own culture, heritage and promote their own culture, to form their own cultural character and personality training, improve the overall quality, create a sound personality.

Accommodating China, landscape scenery, vast land. In the long history of civilization, with its diligence and wisdom of ancient ancestors left us a rich treasure trove of material and bright spirit. My generation learned people, born and raised in and bred, is the most intimate accent, the best understanding of the nostalgia, the most beloved is folks, our home, love more cut deeper mailer. Implementation of the local culture and education, to nurture local culture and profound student of local awareness raising student Han national identity, shaping students' sound personality, when the bounden duty of educators, long way to go.

\section{References:}

[1] Yu WEI Qin Youyu, local awareness and education problems in the theory of localization [J] Education Research, 2009 (6)

[2]Li Guoqiang, Based on the spirit of regional culture Cultural Studies Perspective University [J] Sichuan Institute of Technology, 2012 (8)

[3]Han Yanming, Strengthen cultural educational function of educational research university [J], 2009 (4)

[4] Li Sumei, China hundred local materials evolved Review [J] Guangxi University for Nationalities, 2008 (1)

[5] Helmut Schmidt, Globalization and moral reconstruction [M] Beijing: Social Sciences Academic Press, 2001 (62)

[6]Yang Qifan, Journal of the value of research [J] Chongqing University of Science and geographical characteristics of the Cultural Quality Education in Colleges and Universities 2013 (9) 